\title{
Effects of Some Environmental Factors on Birth Weight of Anatolian Buffalo Calves
}

\author{
Ertuğrul Kul $^{1 *}$, Gökhan Filik², Aziz Şahin ${ }^{1}$, Hayrettin Çayıroğlü ${ }^{1}$, Emre Uğurlutepe ${ }^{1}$, \\ Hüseyin Erdem ${ }^{3}$
}

${ }^{1}$ Department of Animal Science, Faculty of Agriculture, Ahi Evran University, 40100 Kırşehir, Turkey

${ }^{2}$ Department of Agricultural Biotechnology, Faculty of Agriculture, Ahi Evran University, 40100 Kirşehir, Turkey

${ }^{3}$ Department of Animal Science, Faculty of Agriculture, Ondokuz Mayis University, 55200 Samsun, Turkey

\section{A R T I C L E I N F O}

\section{Research Article}

Received 23 November 2017

Accepted 23 March 2018

Keywords:

Anatolian Buffalo calve

Birth weight

Sex of calf

Birth season

Maternal age

A B S T R A C T

\begin{abstract}
This study was conducted to determine the effects of some environmental factors on birth weight (BW) in Anatolian Buffalo calves born in the scope of the project of improvement of Anatolian Buffalo in public hand supported by General Directorate of Agricultural Research and Policies reared in Amasya province of Turkey. A total of 228 heads calves born between 2014 and 2015 were constituted the study material. Sex of calf, maternal age, birth season and location were assessed as affecting factors on BW. The data were analyzed using the SPSS statistical package program. Average BW was determined as $29.3 \pm 0.43 \mathrm{~kg}$. The effects of calf sex, maternal age and birth season on BW were detected to be statistically significant. The average $\mathrm{BW}$ of the male calves $(32.2 \pm 0.57$ $\mathrm{kg}$ ) was found to be higher than those of the female calves $(26.0 \pm 0.50 \mathrm{~kg})$. BW of calves born in autumn had the lowest value. In addition, BW was tented to increase with advanced maternal age.
\end{abstract}

\footnotetext{
*Corresponding Author:

E-mail: ertugrul.kul@ahievran.edu.tr
}

DOI: https://doi.org/10.24925/turjaf.v6i4.444-446.1716

\section{Introduction}

Buffalo raising is one of the important financial income to many countries in the world because of its main source of economic milk and meat (Marai et al., 2001). However, Anatolian Buffalo population as an important genetic resource of Turkey has been reduced drastically during the last few decades (Atasever et al., 2011). Genetic potential for milk and fertility of Anatolian buffalo in Turkey is still low has therefore been declining because researches on buffaloes are very scarce.

Birth weight $(\mathrm{BW})$ is the first observable polygenic character of animal, and it can be considered as the first phenotypic expression of individual's genotype and the difference of their subsequent growth (Yadav et al., 2001). BW is connected to the adaptability and survivability (Zaman et al., 2007) and is also used as an indicator trait in selection programs to decrease the risk of dystocia (Hossein-Zadeh et al., 2012). The BW of buffaloes are influenced by many environmental factors, for example sex of calf (Zaman et al., 2007; HosseinZadeh et al., 2012), maternal age (Thiruvenkadan et al., 2009), birth season (Hossein-Zadeh et al., 2012), location (Zaman et al., 2007), nutrition and etc. These factors may suppress the animal's true genetic potential for growth (Thevarnanoharan et al., 2001). Although factors affecting calf BW in cattle have been studied, reports on the influence of different factors on BW of buffalo calves are scanty (Marai et al., 2001; Çakmak et al., 2013). Thus, further studies are needed to determine on BW of Anatolian Buffalo. The aim of the present study was to investigate the effects of some factors on $\mathrm{BW}$ in Anatolian buffalo calves.

\section{Materials and Methods}

The date were collected from a total of 228 calves born between 2014 and 2015 in Amasya province, Turkey. Amasya province is in the Mid-Black Sea Region of Turkey with $34^{\circ} 57^{\prime} 06^{\prime \prime}-36^{\circ} 31^{\prime} 53^{\prime \prime}$ east longitudes, and $41^{\circ} 04^{\prime} 54^{\prime \prime}-40^{\circ} 16^{\prime} 16^{\prime \prime}$ north latitudes. The province has a climate with a transition feature between a MidBlack Sea maritime climates. Long-term average annual temperature varies from 2.7 to $24.1{ }^{\circ} \mathrm{C}$ and average relative humidity is 52.5 to $69.4 \%$ (MARA, 2015).

BW was obtained from individual farms. The lactating buffaloes grazed outside between April to December, while being kept and fed indoors through the winter. The buffaloes were fed a total mixed ration in winter. Buffalo calves were fed on milk in the morning and evening. The 
environmental factors were evaluated as sex of calf, maternal age, birth season and location. The statistical model assumed for the evaluation of environmental factors on BW was as fallows;

$\gamma_{\mathrm{ijk} \ell \mathrm{m}}=\mu+\mathrm{a}_{\mathrm{i}}+\mathrm{b}_{\mathrm{j}}+\mathrm{c}_{\mathrm{k}}+\mathrm{d}_{\ell}+\mathrm{e}_{\mathrm{ijk} \ell \mathrm{m}}$

$\gamma_{\mathrm{ijk} \ell \mathrm{m}}=$ The $\mathrm{m}^{\text {th }}$ observation in the $\mathrm{i}^{\text {th }}$ sex of calf, $\mathrm{j}^{\text {th }}$ maternal age, $\mathrm{k}^{\text {th }}$ birth season and $\ell^{\text {th }}$ location.

$\mu \quad=$ overall mean,

$\mathrm{a}_{\mathrm{i}} \quad=$ effect of $\mathrm{i}^{\text {th }}$ sex of calf ( $i$ : Male and Female)

$\mathrm{b}_{\mathrm{j}} \quad=$ effect of $\mathrm{j}^{\text {th }}$ maternal age ( $\mathrm{j}: 3$ to 10$)$

$\mathrm{c}_{\mathrm{k}} \quad=$ effect of $\mathrm{k}^{\text {th }}$ birth season ( $k$ : Autumn, Winter, Spring and Summer)

$\mathrm{d}_{\ell}=$ effect of $\ell^{\text {th }}$ location ( $\ell$ : Goynucek, Gumushacikoy, Hamamozu, Merkez, Merzifon, Suluova and Tasova)

$\mathrm{e}_{\mathrm{ijk} \ell \mathrm{m}}=$ Random error.

All statistical analyses were examined by using general linear model in SPSS for Windows statistical package program (SPSS, 13.00). Significance of the differences among means were compared with Duncan's multiple range test $(\mathrm{P}<0.05)$.

\section{Results and Discussion}

The analysis of variance results for the evaluation of the influence of sex, maternal age, birth season and location on $\mathrm{BW}$ is given in Table 1 . The overall mean BW in the present study was found as $29.3 \pm 0.43 \mathrm{~kg}$. This result was higher than Sahin and Ulutas (2013), and lower than the values found by Çakmak et al. (2013) in Anatolian Buffalo calves. However, BW determined in this research was lower than the values found in the some studies with different breeds (Thevarnanoharan et al.,
2001; Barbosa et al., 2006; Kaygisı, 2008; Thiruvenkadan et al., 2009).

In the present study, the effect of sex on BW was determined to be statistically significant $(\mathrm{P}<0.01)$. The overall mean BW was found to be $32.2 \pm 0.57 \mathrm{~kg}$ for male calves and $26.0 \pm 0.50 \mathrm{~kg}$ for female calves (Table 1). $\mathrm{BW}$ of male calves was $6.2 \mathrm{~kg}$ heavier than female calves. Also, the result of this study was closely in agreement with some study results (Thevarnanoharan et al., 2001; Zaman et al., 2007; Hosein-Zadeh et al., 2012; Çakmak et al., 2013; Sahin and Ulutas, 2013) in which reported BW of the male calves was higher than female calves. Hossein-Zadeh et al. (2012) emphasized that this effect could be probably due to greater body size of male calves than female. In the present study, this finding indicates that sex of calve was an important parameter for BW. In contrary, Yadav et al. (2004) reported that sex on BW had no significant effect.

As seen from Table 1, BW of the calves increased with maternal age $(\mathrm{P}=0.031)$. As parallel with this case, some researchers (Thevarnanoharan et al., 2001; Thiruvenkadan et al., 2009; Sahin and Ulutas, 2013) reported that effect of maternal age on BW was significant. While Hossein-Zadeh et al. (2012) indicated that calves of older buffaloes had the highest BW, Rao and Rao (1996) estimated that BW in Murrah males was significantly lower in the first parity calves than that of the later parity calves. Thevarnanoharan et al. (2001) emphasized that the buffaloes in the earlier parities produced lighter calves than those in the later parities. Conversely, Zaman et al. (2007) found that effect of parity on BW was not significant. One explanation of these results is that early-parity buffalos continue to grow until reaching adult size and may compete with the fetus for available nutrients during pregnancy (Koçak et al., 2007).

Table 1 Means of birth weight in Anatolian Buffaloes

\begin{tabular}{|c|c|c|c|c|}
\hline \multicolumn{2}{|c|}{ Factors } & \multirow{2}{*}{$\begin{array}{c}\mathrm{n} \\
119 \\
109\end{array}$} & \multirow{2}{*}{$\begin{array}{c}\bar{X} \pm S_{\bar{X}} \\
32.2 \pm 0.57^{\mathrm{a}} \\
26.0 \pm 0.50^{\mathrm{b}}\end{array}$} & \multirow{2}{*}{$\frac{P \text {-value }}{<0.001}$} \\
\hline Sex & $\begin{array}{l}\text { Male } \\
\text { Female }\end{array}$ & & & \\
\hline Maternal Age & $\begin{array}{l}3 \\
4 \\
5 \\
6 \\
7 \\
8 \\
9 \\
10 \\
\end{array}$ & $\begin{array}{l}45 \\
34 \\
44 \\
36 \\
24 \\
11 \\
16 \\
18 \\
\end{array}$ & $\begin{array}{c}27.9 \pm 0.82^{\mathrm{ab}} \\
26.5 \pm 0.86^{\mathrm{b}} \\
31.3 \pm 1.13^{\mathrm{a}} \\
30.2 \pm 1.15^{\mathrm{ab}} \\
29.3 \pm 1.15^{\mathrm{ab}} \\
30.1 \pm 1.45^{\mathrm{ab}} \\
28.1 \pm 1.68^{\mathrm{ab}} \\
31.2 \pm 1.93^{\mathrm{a}} \\
\end{array}$ & 0.031 \\
\hline Birth Season & $\begin{array}{l}\text { Autumn } \\
\text { Winter } \\
\text { Spring } \\
\text { Summer }\end{array}$ & $\begin{array}{l}26 \\
19 \\
92 \\
91 \\
\end{array}$ & $\begin{array}{l}26.8 \pm 0.87^{\mathrm{b}} \\
29.6 \pm 1.29^{\mathrm{a}} \\
29.2 \pm 0.74^{\mathrm{a}} \\
29.9 \pm 0.69^{\mathrm{a}} \\
\end{array}$ & 0.048 \\
\hline Location & $\begin{array}{l}\text { Suluova } \\
\text { Tasova } \\
\text { Goynucek } \\
\text { Gumushacikoy } \\
\text { Merkez } \\
\text { Merzifon } \\
\text { Hamamozu }\end{array}$ & $\begin{array}{c}37 \\
65 \\
29 \\
17 \\
36 \\
40 \\
4 \\
\end{array}$ & $\begin{array}{l}27.0 \pm 0.91 \\
28.8 \pm 0.81 \\
29.4 \pm 1.10 \\
29.7 \pm 1.99 \\
30.4 \pm 1.15 \\
30.6 \pm 0.99 \\
31.1 \pm 4.72 \\
\end{array}$ & ns \\
\hline & Overall & 228 & $29.3 \pm 0.43$ & \\
\hline
\end{tabular}


Table 1 shows that effect of birth season on BW was statistically significant $(\mathrm{P}=0.048)$. Similarly, Marai et al. (2001), Thevarnanoharan et al. (2001) and Sahin and Ulutas (2013) found that BW in calves was significantly affected by calving season. Thevarnanoharan et al. (2001) determined that $\mathrm{BW}$ of the calves born in the winter was the lowest. Marai et al. (2001) expressed that the highest BW was measured in autumn and the lowest BW was recorded in winter and spring seasons. Naqvi and Shami (1999) reported that male calves born in spring were heavier than those of the calves born in summer. This may be caused by differential availability of pasture due to variable weather conditions during autumn season (Messine et al., 2007). Because, pasture and grazing composition during in this season which is transition period, is deteriorated. However, these results were not supported with the study reports of Hossein-Zadeh et al. (2012) and Thiruvenkadan et al. (2009).

Table 1 also presents that effect of location on BW was not significant. This result was in agreement with earlier results conducted in different breeds by Yadav et al. (2004) and Hossein-Zadeh et al. (2012). Differences of the findings between present study and the others could be explained by variations among the breeds, regions or climate.

\section{Conclusion}

This research revealed the importance of environmental factors such as sex of calf and maternal age on BW of buffalo calves. It was determined that male calves were significantly heavier than female calves. Consequently, the effects of non-genetic factors must be taken into account to provide the best estimates of genetic parameters and breeding values in the Anatolian Water Buffalo for selection. However, further investigations on BW and other traits of Anatolian buffalo calves should also be carried out.

\section{Acknowledgement}

This research was supported financially by Republic of Turkey, Ministry of Food, Agriculture and Livestock, General Directorate of Agricultural Research and Policies. We would like to thank Amasya Water Buffalo Breeders' Association for valuable technical assistance.

\section{References}

Atasever S, Erdem H, Kul E. 2011. Relationship between somatic cell count and catalase activity in raw milk of Anatolian Buffaloes. Scientific Research and Assays, 6(19): 4109-4112.

Barbosa SBP, Lopes CRA, Pereira RGA, Santoro KR, López ORM, Rezende FM. 2006. Environmental and inherited factors as sources of variation in buffalo birth weight. 8th World Congress on Genetic Applied to Livestock Production, August 13-18, Belo Horizonte, MG, Brasil.

Çakmak A, Çelik İ, Kaya E, Koç A. 2013. A research on calf birth weight, milk constituents and somatic cell count of Anatolian Buffaloes. IX. National Animal Science Student Congress, 23-25 May 2013, p.141-150, Erzurum, Turkey.

Hossein-Zadeh N, Madad M, Shadparvar AA, Kianzad D. 2012. An observational analysis of secondary sex ratio, stillbirth and birth weight in Iranian Buffaloes (Bubalus Bubalis). J. Agr. Sci. Tech., 14: 1477-1484.

Kaygis1z A. 2008. Effect of inbreeding on birth weight of Turkish Buffalo. Indian Journal of Animal Sciences, 78(6): 655.

Koçak S, Tekerli M, Özbeyaz C, Yüceer B. 2007. Environmental and genetic effects on birth weight and survival rate in Holstein calves. Turk. J. Vet. Anim. Sci. 31(4): 241-246.

MARA. 2015. The master plan of Amasya province. MARA statistical data of Amasya province, Amasya.

Marai LFM, Farghaly HM, Nasr AA, Abou-Fandoud EI, Mohamed IAS. 2001. Buffalo cow productive, reproductive and udder traits and stayability under sub-tropical environmental conditions of Egypt. Journal of Agriculture in the Tropics and Subtropics, 102: 1-14.

Messine O, Schwalbach LJM, Mbah DA, Ebangi AL. 2007. Non-genetic factors affecting gestation length and postpartum intervals in Gaudily Zebu cattle of the Adamawa Highlands of Cameroon. Tropicultura, 25: 129-133.

Naqvi AN, Shami SA. 1999. Factors affecting birth weight in Nili-Ravi buffalo calves. Pakistan Vet. J., 19(3): 119-122.

Rao AVN, Rao HRM. 1996. Effect of some non-genetic factors on growth rate of Murrah male calves. Indian Veterinary Journal, 73(11): 1193-1194.

Sahin A, Ulutas Z. 2013. Non genetic factors affecting various growth traits of Anatolian Buffalo calves. $\mathrm{VI}^{\text {th }}$ International Balkan Animal Conference (BALNIMALCON). 3-5 October 2013, Tekirdag, Turkey.

SPSS 2004. Windows User's Guide. Version 13.0, SPSS Inc., Michigan Ave., Illinois, USA, Chicago.

Thiruvenkadan AK, Panneerselvam S, Rajendran R. 2009. Nongenetic factors influencing growth performance in Murrah Buffalos. South African Journal of Animal Science, 39(1): 102-106.

Thevarnanoharan K, Vandepitte W, Mohiuddin G, Chantalakhana C. 2001. Environmental factors affecting various growth traits of Swam: P Buffalo calves. Pak. I. Agri. Sci., 38(3-4): 5-10.

Yadav BS, Yadav MC, Singh A, Khan FH. 2001. Murrah Buffaloes-I. Birth weight. Buffalo Bullettin, 20(2): 29-31.

Zaman G, Goswami RN, Aziz A. 2007. Factors affecting gestation period and birth weight in Swamp Buffaloes of Assam. Indian J. Anim. Hlth., 46(1): 33-36. 